Reprod. Nutr. Dévelop. 1980, 20 (4 A), 1073-1079.

\title{
Recent methods for the investigation of the accessory glands of the human male genital tract
}

\author{
par J. P. PRYOR
}

Institute of Urology, London University, 172 Shaftesbury Avenue, London WC2 H 8JE, Angleterre.

The gross anatomy of the accessory glands of the human male genital tract has been known for many centuries but even today there is only scant knowledge about the function of these organs. Reference to the text of Mann (1964) and to books edited by Greep and Astwood (1975) and Brandes (1974) provide a wealth of information about mammalian accessory gland function but serve only to emphasize how little is known about human physiology. The proceedings of a conference on « Human Semen and Fertility Regulation in man » Hafez (1976) serves as a starting point for this review of recent methods for investigating the accessory glands of the human male genital tract.

\section{Radiological investigations.}

Figure 1 shows the appearance of Cowper's gland and its duct as seen on an ascending urethrogram. I am unable to comment on the appearance of this gland nor am I able to provide you with any reliable information on the physiology of its secretions. The radiological appearances of the epidydimis, vas deferens, seminal vesicle and ejaculatory ducts may be demonstrated by the injection of contrast medium through a 25-gauge hypodermic needle which penetrates through the wall of the exposed vas deferens. This is facilitated by placing a ligature around the vas in order to make entry into the lumen easier. Boreau (1974) has published a magnificent book on vasography but most surgeons rarely find the epidydimal studies of any practical value, and often confine themselves to the injection of saline along the vas deferens to confirm its patency. This may give a false positive as has occurred to me on two occasions in the past year. There was a free flow of fluid along the vas on each occasion but the fluid emptied into an impalpable and unsuspected prostatic utricle and - also filled the opposite vas by retrograde filling (fig. 2). The forcible injection of further contrast led to the escape of contrast into the prostatic urethra and bladder. Buck, Sherwood and Pryor (1977) reviewed 96 vasograms and found abnormalities - usually obstructive - in 37 p. 100 of the men with azoospermia and in 19 p. 100 (usually inflammatory changes) in men with oligozoospermia.

The filling of the vas deferens and seminal vesicle with radio-opaque contrast medium (Miksuya et al., 1960) makes it possible to study ejaculation, and technical 
improvements in the quality of imaging and video recording greatly facilitates this. Such a study alerted us to an unsuspected and unexplained defect in the bladder neck mechanism, and patients with unexplained primary ejaculatory failure or retrograde ejaculation should certainly be undergoing urodynamic investigation.

The synchronous combined video-pressure flow cystourethrographic techniques described by Whiteside and Bates (1979), are a useful basis for these studies which should also include an assessment of the urethral pressure profile (Abrams, 1979 ; Tanagho, 1979). It is then possible to detect abnormalities of the bladder neck and external sphincter function which are not readily apparent by other methods and to avoid labelling these patients as having psychological problems.

\section{Examination of the semen.}

In 1786 John Hunter drew attention to the differences between the first and last part of the ejaculate and examination of the split ejaculate has provided much useful information. Eliasson and Lindholmer (1976) report the results of splitting the ejaculate into 6 portions and confirm that acid phosphatase of prostatic origin appears early, whilst the fructose, from the seminal vesicles, is to be found in the last part of the ejaculate. The relationship of other substances in the split ejaculate to those of known origin provides evidence as to their origin, but it should be remembered that different secretions of the accessory glands may occur in response to stimuli of differing nature and intensity.

During the past five years many substances have been identified and measured in human seminal plasma. These range from «simple » chemicals (Barkan ef al., 1978 ; Keil, Weltraver and Hert, 1979 ; Nissen ef al., 1979 ; Papp et al., 1979), to enzymes (Menella and Jones, 1977 ; Beer ef al., 1978 ; Chapdelaine ef al., 1978), prostaglandins (Jelly, 1978) and hormones (Segal ef al., 1978 ; Milbradt, Linzbach and Feller, 1979), but the relationship of these to human fertility remains obscure in most instances. Carnitine and glyceryl phosphocholine are markers of epidydimal function and may be of value in the diagnosis of obstructive lesions of the seminal tract (Sade et al., 1978 ; Wetteraver and Heite, 1978 ; Frankel and Lewin, 1979).

\section{Detection of infection.}

The importance of infection in human infertility is well recognised but debate continues as to the incidence as a specific cause of infertility. Infection would appear to be of major importance in Scandinavia (Eneroth ef al., 1978 ; Nikkanen ef al., 1979) but it seems to be less of a problem in the United States (Leonard, Capell and Paulsen, 1976) or England. These differences reflect variations in disease incidence as was shown by the frequency with which our technicians reported the presence of pus cells

FIG. 1. - Ascending urethrogram showing Cowper's gland and its duct.

FIG. 2. - Unilateral vasogram to show filling of a cystic prostatic utricle and retrograde filling of the opposite vas deferens. 

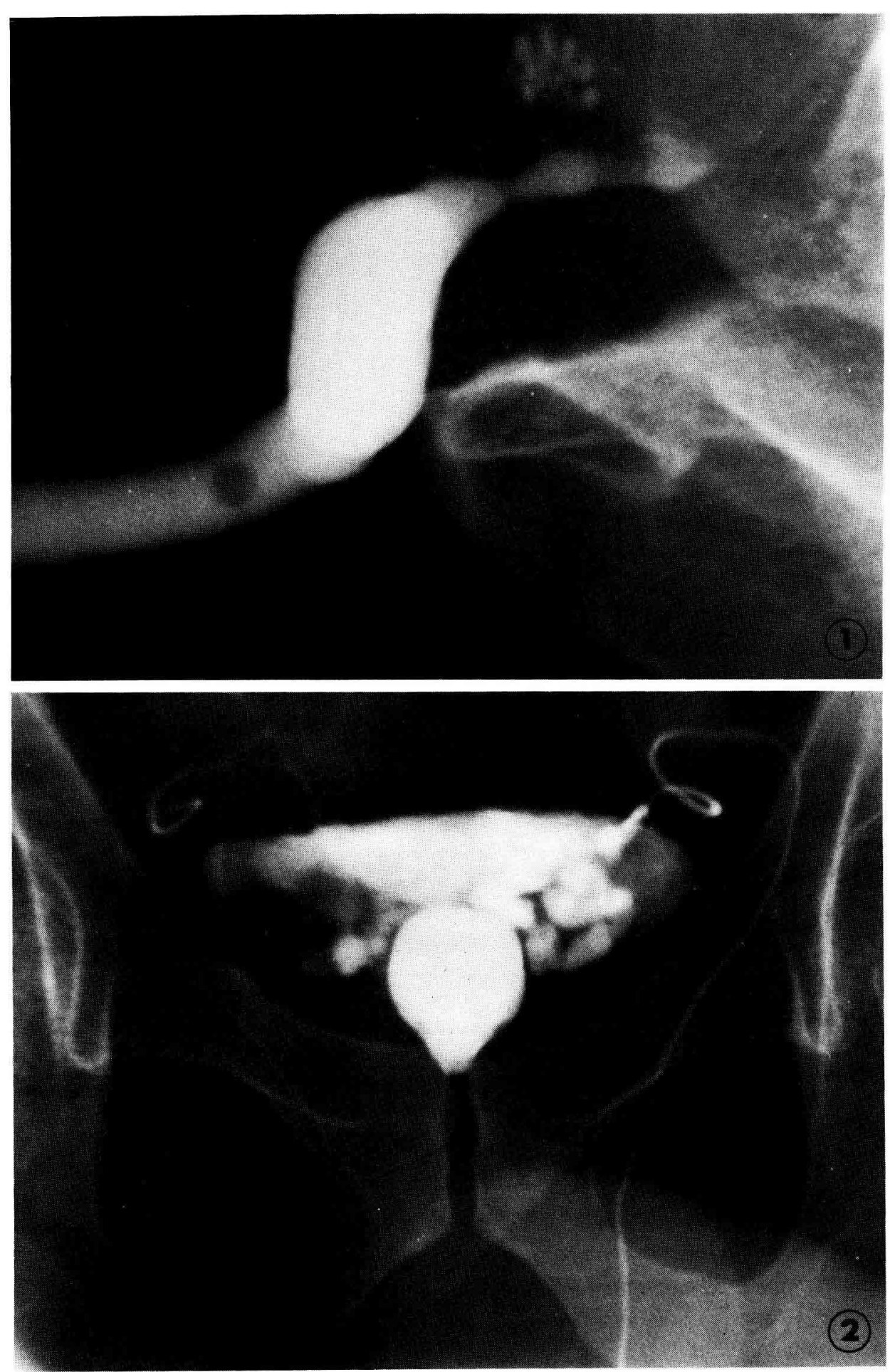
in the routine seminal analysis of infertile men (Pryor, 1978). In a retrospective study pus cells were noted in 9 p. 100 of 100 United Kingdom residents, 66 p. 100 of those patients from overseas (range 0-91 p. 100).

The diagnosis of infection of the male accessory genital organs remains indefinite with no clear relationship between the sympiomology, palpatory findings, the bacteriological, cytological and biochemical analysis of the seminal or expressed prostatic fluid or even the histological appearance of the prostate. Cytological studies of expressed prostatic fluid have been found useful in monitoring the response to treatment (Eliasson and Johannisson, 1978). In the absence of objective findings of infection many andrologists resort to a therapeutic trial in an attempt to improve the fertility of the patients.

The choice of an antibiotic in the treatment of the male accessory gland infection depends not only upon the sensitivity of the organism and the duration of treatment (usually for three months), but also upon choosing an antibiotic which appears in the seminal fluid. This can be ensured by measuring the concentration of the antibiotic in seminal plasma or in the prostatic tissue removed by endoscopic resection following the oral or intravenous administration of the antibiotic (Eliasson and Dornbusch, 1977).

\section{Antibody studies.}

Immunological factors are felt to be an important cause for infertility in 5 to 10 p. 100 of infertile couples (Hendry, Morgan and Stredonska, 1977 ; Boettcher, 1978). Auto antibodies against spermatozoa are most conveniently detected in plasma and high titres of antibody are usually associated with the presence of auto antibodies in the seminal plasma (Rumtke, 1978). It is here that the « antibody » is of importance and forms the basis of the shaking movement seen in Kramer's sperm cervical mucus test (Kraemer and Jager, 1976). The clinical value of such testing has been well documented (Hendry, Morgan and Stredonska, 1977).

\section{Investigation of prostatic function.}

Acid phosphatase is a well recognized indicator of prostatic function and is of value in the assessment of prostatic cancer. It has previously been measured by enzymatic methods but it is likely that these will be replaced by the radioimmunoassay of prostatic acid phosphatase (Cooper and Foti, 1974). This method may also be sufficiently accurate to allow the diagnosis of prostatic cancer by examination of peripheral plasma (Foti, Cooper and Herschman, 1977).

Transrectal biopsy with the disposable Bardic Needle has become the method of choice for obtaining a prostatic biopsy. It does however carry a high rate of bacteraemia and prophylactic antibiotics should always be given.

Unsuccessful attempts have been made to relate hormone concentrations to the occurrence of benign prostatic hypertrophy or carcinoma of the prostate. More promising have been the attempts to correlate changes in the different hormone ratios with the presence of these diseases (British Prostate Study Group, 1979). Dynamic studies on the uptake and metabolism, of androgens by prostatic tissue carried out by Professor Collins served only to show that there were many inter-related regula- 
tory mechanisms (Collins ef al., 1975). More recently interest has centred on the androgen receptors in prostatic tissue but the value of these studies has yet to be fully assessed (Ghanadian ef al., 1978).

\section{Investigation of epidydimal function.}

The major obstacle to investigating the human epididymis is the difficulty in obtaining material from fertile men. Mooney, Horum and Lattimer (1972) obtained epididymides from patients undergoing orchidectomy for carcinoma of the prostate and found that spermatozoa obtained from the caput showed an 11.5 p. 100 motility whereas 34.4 p. 100 of those spermatazoa obtained from the cauda epididymis were motile. Clinical studies on the results of patients undergoing epididymo-vasostomy have shown that 73 p. 100 of 44 patients having an anastomosis in the caput epididymis were subsequently found to have spermatozoa in the ejaculate but only 4 pregnancies ensued. In marked contrast to this were the 19 patients with an anastomosis between the corpus epididymis and the vas ; 50 p. 100 of these patients had a patent anastomosis with spermatozoa in the ejaculate and 5 pregnancies ensued (Schmidt, Schoysman and Stewart, 1976). The findings of these two studies suggest that the human epididymis has similar functions to those observed in mammalian physiology.

The general morphology of the human epididymis is well known but full detailed studies are lacking due to the difficulty in obtaining samples from fertile men and to poor fixation. It has been possible to obtain samples of human epididymis from selected volunteers undergoing vasectomy, and then only taking epididymal tissue on the one side in order to leave the possibility of subsequent vasectomy reversal. The morphological features are being quantitated using image analysis by Dr. Moores at the Wellcome Research Unit of the London Zoological Society. In general, the fine structure of the human epididymis was similar to that seen in the old world monkeys but the different regions of the epididymal epithelium of man are much less distinct than those observed in common laboratory animals such as the rat and rabbit. The most abundant epithelial cell type was the principal cell which is characterised by a large supranuclear Golgi complex, numerous profiles of rough endoplasmic reticulum and long microvilli. The principal cell of the human epididymis contains numerous electron-dense, membrane bound granules in the infranuclear cytoplasm close to the basement membrane, whose origin and function is unknown. The apical and basal cell types resemble those found in monkey epididymides. Quantitation of the morphological features of the human epididymis is still in progress and comparisons are being made with tissue from non-human primates.

In collaboration with Hinton and Setchell in Cambridge, we have been able to obtain fluid from the lumen of the human ductus deferens at the time of vasectomy and this has shown that inorganic and organic compounds present in the luminal fluid of other species (Hinton, Snoswell and Setchell, 1979) are also present in the luminal fluid in the human ductus deferens but in different concentrations. The inorganic irons appear to be present in the human luminal fluid in greater concentrations that the organic compounds. This is a clear indication of species difference in physiological patterns and we await with interest the analysis of fluid obtained by micropuncture of the human epididymis at the time of vasectomy. 


\section{Conclusion.}

Infertility, benign prostatic enlargement and carcinoma of the prostate are common problems and of great clinical importance. Attempts to alter the natural history of these conditions have been thwarted by the lack of basic physiology of the funcfioning of the human male accessory organs. It is only by increasing the liaison befween the clinician and basic scientist that our knowledge of human physiology can be improved and those processes with species variation identified.

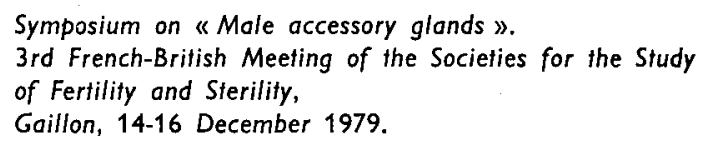

Résumé. L'auteur passe en revue les différentes méthodes d'étude des glandes annexes de l'appareil génital de l'homme :

- Radiologie : vasographie, vésiculographie, urétro-cystographie.

- Examens du sperme : (a) Sur éjaculat fractionné donnant une information sur les différentes glandes annexes : phosphatases acides pour la prostate, fructose pour les vésicules séminales. (b) Sur éjaculat total : composants « simples», enzymes, prostaglandines, hormones... Mais la relation de ces composants avec la fertilité est encore inconnue pour beaucoup d'entre eux.

- Détection d'agents infectieux (dont l'origine est souvent difficile à établir).

- Recherche d'anticorps contre les spermatozoïdes dans le plasma séminal.

Enfin, il développe de manière plus approfondie l'étude de la fonction prostatique et celle de la fonction épididymaire.

II conclut sur la nécessité d'augmenter les liaisons entre cliniciens et chercheurs pour améliorer nos connaissances en physiologie humaine.

\section{References}

ABRAMS, P. H., 1979. Perfusion urethral profilometry. Urol. clin. North Amer., 6, 103-110.

BARKAN T. G., PAZ Z. T., HOMONNAI R., CHAYN R., KRAICER P. F., 1978. Spermine and citric acid in human prostatic fluid. Int. J. Androl., 1, 393-396.

BEER R. M., WEISSELBERG, M., SOFFER Y., LEWIN L. M., 1978. Human seminal fluid gammaglutamyl transferase : 4 prostatic marker enzyme. Int. J. Androl., 1, 405-410.

BOETTCHER B., 1978. Immunology. Int. J. Androl., 1, Suppl. 1, 116-123.

BOREAU J., 1974. Les images des voies séminales. Karger, Bâle.

BRANDES D. 1974. Mole accessory sex orgons, Acad. Press, New York.

BRITISH PROSTATE STUDY GROUP, 1979. Evaluation of plasma hormone concentrations in relation to clinical staging in patients with prostatic cancer. Brit. J. Urol., 51, 382-389.

BUCK C., SHERWOOD T., PRYOR J. P., 1977. Unpublished paper at Royal Society of Medicine

CHAPDELAINE P., TREMBLAY R., DUBE J., St-YVES C., MAILHOT J., 1978. Origin of maltase and variations in infertile men. Arch. Androl., 1, 61-68.

COLLINS W. P., TYLER J. P., KILPATRICK M. J., PRYOR J. P., COLLINS P. M., 1975. Dynamic aspects of androgen metabolism in human prostatic tissue, 96-115. In U. BRACCI, F. DE SILVERIO, Hormonal therapy. Proceed. Int. Meet., Rome.

COOPER J. F., FOTI A. G., 1974. A radioimmunoassay for prostatic acid phosphatase. 1. Methodology and range of normal male serum values. Invest. Urol., 12, 98-102.

ELIASSON R., DORNBUSCH K., 1977. Levels of trimethoprim and sulpha methoxazole in human seminal plasm. Andrologia, 9, 195-202.

ELIASSON R., JOHANNISSON E., 1978. Cytological studies of prostatic fluids from men with and without abnormal palpatory findings of the prostate. Inf. J. Androl., 1, 582-588. 
ELIASSON R., LINDHOLMER, C., 1976. Functions of male accessory genifal organs, 44-50. In HAFEZ E. S. E., Human semen and fertility regulation in men. Moshy C. V., St. Louis.

ENEROTH P., LJANGH-WADSTROM A., MOBERY P. J.,'NORD C.-E., 1978. Studies on the bacterial flora in semen from males in infertile relations. Int. J. Andro!., 1, 105-116.

FOTI A. G., COOPER J. F., HERSCHMAN H., 1977. Detection of prostatic cancer by solid phase radioimmunoassay of serum prostatic and phosphatase. New Engl. J. Med., 297, 1357-1361.

FRANKEL J., LEWIN L. M., 1979. Investigations on carnitine derivations in human seminal fluid. Int. J. Androl., 2, 299-307.

GHANADIAN R., AUF G., CHISHOLM G. D., O'DONOGHUE E. P. N., 1978. Receptor proteins for androgens in prostatic disease. Brit. J. Urol., 50, 567-569.

GREEP R. O., ASTWOOD E. B., 1975. Handbook of Physiology, Sect. 7, Endocrinology, Reproductive system in the male : Vol. 3. Am. Physiol. Soc., Washington.

HAFEZ E. S. E., 1976. Human semen and fertility regulation in men. Mosby C. V. St. Louis.

HENDRY W. F., MORGAN H., STEDRONSKA J., 1977. The clinical significance of antisperm antibodies and infertility. Brit. J. Urol., 49, 757-762.

HINTON B. T., SNOSWELL A. M., SETCHELL B. P., 1979. The concentration of carnitine in the luminal fluid of the testis and epidydimis of the rat and some other mammals. J. Reprod. Fert., 56, 105-111.

JELLY R. W., 1978. Prostaglandins in the semen : their occurrence and possible physiological significance. Int. J. Androl., 1, 188-200.

KEIL M., WELTRAVER U., HERT J. H., 1979. Glutamic acid concentration in human semen, its origin and significance. Andrologia, 11, 385-390.

KRAEMER J., JAGER S., 1976. The sperm cervical mucus contact test : A primary report. Fert. Steril., 27, 335-340.

LEONARD J. M., CAPELL P. T., PAULSEN C. A., 1976. Semen analysis : Importance in evaluation of male infertility. Andrologia, 8, Suppl. 1, 61-68.

MANN T., 1964. The biochemistry of the semen and of the male reproductive tratc. Methuen \& Co, London.

MENNELLA M. R. F., JONES R., 1977. The activity of some muleolytic enzymes in semen and its secretions of the male reproductive tract. Andrologia, 9, 15-22.

MIKSUYA H., ASAI J., SUYAMA K., USHIDA T., HOSOE K., 1960. Application of X-ray cinematography in urology, mechanism of ejaculation. J. Urol., 83, 86-92.

MILBRADT R., LINZBACH P., FELLER H., 1979. Average concentrations of FSH and LH in seminal plasma as determined by radioimmunoassay. Andrologia, 11, 127-134.

MOONEY J. K., HORUM A. H., LATTIMER J. K., 1972. Motility of spermatozoa in the human epididymis. J. Urol., 108, 443-445.

NIKKANEN V., GRONOOS M., SUOMINEN J., MULTAMAKI S., 1979. Silent infection in male accessory genital organs and male infertility. Andrologia, 11, 236-241.

NISSEN H. P., SCHIRREN C., KREYSEL H. W., HEINZE I., 1979. Amino acid composition of human semen from different clinical diagnoses. Andrologia, 11, 109-110.

PAPP G. Y., GROF J., MOLNAR J., JAMBAR E., 1979. Die rolle des arginingehaltes und der Arginareaktivitat in der fertilitat. Andrologia, 11, 37.41.

PRYOR J. P., 1978. Geographical variation in the incidence of leucocytes in the semen of infertile men. Int. J. Androl., Suppl. 1, 164.

RUMTKE PH., 1978. Autoantibodies against spermatozoa, 67-79. in COHEN J., HENDRY W. F., Spermatozoo, antibodies and infertility, Blackwell, Edinburgh.

SADE M. S., VERYMUTTU I., DIRISDALE O., GOW J. G., 1978. The management of azoospermia Brit. J. Urol., 50, 595-597.

SCHMIDT S. S., SCHOYSMAN R., STEWART B. H., 1976. Surgical approaches to male infertility, 476-493. In Human semen and fertility regulation in men, HAFEZ E. S. E., Mosby, St. Louis.

SEGAL S., RON M., LAUFFAR N., BEN DAVID M., 1978. Prolaction in seminal plasma of infertile men. Arch. Androl., 1, 49-52.

TANAGHO E. A., 1979. Membrane and Micro transducer catheters : their effectiveness for profilometry of the lower urinary tract. Urol. clin. North Amer., 6, 110-117.

WETTERAUER U., HEITE H. J., 1978. Carnitine in seminal fluid as a parameter for epididymal function. Andrologia, 10, 203-210.

WHITESIDE G., BATES P., 1979. Synchronous video pressure flow cystourethrography. Urol. clin. North Amer., 6, 89-102. 